\title{
Analysis of the Emotion Regulation Inventory through IRT
}

\author{
Mirela Dantas Ricarte ${ }^{1}$ \\ Fernanda Mírian França Silva \\ José Maurício Haas Bueno ${ }^{1}$ \\ ${ }^{1}$ Universidade Federal de Pernambuco, Recife, PE
}

\begin{abstract}
Emotion regulation is a multiprocessual phenomenon capable of maintaining, intensifying or diminishing the emotional experience. This work investigated the psychometric properties of the Emotion Regulation Inventory for Learning Situations, using the Item Response Theory (IRT). Participants included 365 students from the 5th to the 9th grades of elementary school, with a mean age of 11.9 years $(S D=1.72), 57.5 \%$ female and $42.5 \%$ male. The results indicated problems in the instrument, such as small variability of the items and underutilized categories of response, and ways for the revision of the instrument, such as construction of more difficult items that require internal strategies, focused on the learning experience.

Keywords: emotion regulation, learning, emotional intelligence.
\end{abstract}

Análise do Inventário de Regulação Emocional por meio da TRI

\begin{abstract}
Resumo
A regulação das emoções caracteriza-se por ser um fenômeno multiprocessual capaz de manter, intensificar ou diminuir a experiência emocional. Este trabalho se propôs a investigar as propriedades psicométricas do Inventário de Regulação de Emoções para Situacões de Aprendizagem (IREmos Aprender), com o auxílio da Teoria de Resposta ao Item (TRI). Participaram deste estudo 365 alunos do $5^{\circ}$ ao $9^{\circ}$ ano, com idade média de 11,9 anos $(D P=1,72)$, sendo $57,5 \%$ do sexo feminino e $42,5 \%$ do sexo masculino. Os resultados permitiram a identificação de problemas nas escalas do instrumento, como a pouca variabilidade dos itens e a existência de categorias subutilizadas de respostas, e de possíveis caminhos a serem adotados na sua revisão, como a construção de itens mais difíceis que exijam estratégias internas, focadas na experiência de aprendizagem.
\end{abstract}

Palavras-chave: regulação emocional, aprendizagem, inteligência emocional

\section{Análisis del Inventario de Regulación Emocional por medio de la TRI}

\begin{abstract}
Resumen
La regulación emocional se caracteriza por ser un fenómeno de multiprocesamiento capaz de mantener, intensificar o disminuir la experiencia emocional. Este estudio tuvo como objetivo investigar las propiedades psicométricas del Inventario de Regulación de las Emociones para Situaciones de Aprendizaje (IREmos Aprender), con el auxilio de la Teoría de Respuesta al Ítem (TRI). Participaron 365 alumnos de $5^{\circ}$ a $9^{\circ}$ año, con promedio de edad 11,9 años $(D P=1,72)$, de los cuales $57,5 \%$ eran de sexo femenino y $42,5 \%$ de sexo masculino. Los resultados permitieron identificar problemas en las escalas del instrumento, tales como, poca variabilidad de los ítems, existencia de categorías subutilizadas de respuestas y posibles caminos a ser adoptados en la revisión como la construcción de ítems más difíciles que exijan estrategias internas, centradas en la experiencia de aprendizaje.

Palabras clave: regulación emocional, aprendizaje, inteligencia emocional
\end{abstract}

Emotion regulation (ER) is a theme that has long aroused human interest and it has been explored in several areas of knowledge, such as philosophy, religion and literature. Throughout the last century it was also studied in psychology, being approached by Freud (1926/1976), for example. In the mid-1990s scientific interest in this subject has increased and an increasing number of published studies on the subject was observed. Mayer and Salovey $(1990,1997)$, for example, have included it as one of the skills of emotional intelligence, while Saarni (1999) situated it in the field of emotional competences.

However, it was Gross (1998) who placed it in the field of study of emotions. In this sense, it is known that emotion is characterized by emerging from a series of physiological, behavioral and psychic changes, when the individual is confronted with a relevant situation to which he attributes a particular meaning (Barrett, Ochsner, \& Gross, 2007; Gross, 1998, 2008). Based on these characteristics and on the flexibility or malleability aspect of the emotional experience, Gross (1998) took the modal model of emotion as a reference for the elaboration of a theory about emotion regulation. This was also the model adopted to base the construction of the instrument investigated in this study.

This model states that emotional experience can be understood by a sequence of four subsequent steps: situation, attention, evaluation, and response. In this 
perspective, the emotion regulation can occur in any of these stages and is characterized as a multi procedural phenomenon capable of maintaining, intensifying or diminishing the emotional experience, in relation to emotions considered either positive or negative, in a given context (Gross \& Thompson, 2007). Considering these four stages of emotional experience, Gross (1998; 2008) outlines five strategies of emotion regulation, interposed to the steps mentioned: situation selection, situation modification, attentional deployment, cognitive change (evaluation) and response modulation.

Situation selection involves choosing the situation in which a person will engage in such a way, usually to avoid negative emotions or to favor positive emotions. While the situation selection is a strategy used before the occurrence of a situation that would generate some emotional impact, the situation modification refers to the action of the individual to change an already existing situation, aiming at reducing the emotional impact experienced. However, if the situation selection or modification are not possible or recommended, perhaps one can at least choose in which part of the environment attention will be focused. In this sense, attentional deployment is the regulation strategy that concerns the way individuals control their attention to influence their emotions, whether through distraction, physical or sensory distance from the situation, internal (thought) or external (responding to other demands) redirection of attention. Cognitive change, in turn, is a strategy of regulating emotions that concerns the modification of the meaning given by the individual to the triggering situation of emotion (evaluation), also involving the way one perceives his or her capacity to deal with such a situation. Finally, response modulation contemplates efforts to regulate physiological, experiential and behavioral responses as far as possible (Gross, 1998; 2008; 2015).

In a more recent study, Gross (2015) identified that emotional experience can be understood in its dynamic aspects, describing it through evaluation systems that occur in a simultaneous and interposed way. According to the author, all emotion involves an evaluation process in which its quality is discriminated, and this occurs in the following direction: (a1) world $\rightarrow$ (b1) perception $\rightarrow$ (c1) evaluation $\rightarrow$ (d1) action $\rightarrow$ (a2) world, occurring cyclically and continuously over time. Thus, emotional experience can be understood as a spiral of evaluation systems that succeed each other in time and at each stage of the process this experience is outlined.

Therefore, different systems of valuation are activated simultaneously while an individual lives daily emotional experiences, and it is in the interaction between them that ER is pinpointed. According to the "extended model of emotion regulation" (Gross, 2015), regulation occurs when a second-level valuation system (2) acts upon a first-level valuation system (triggering of emotion), discriminating the emotional experience as positive or negative and acting to modify it according to the person's goals. The five strategies for regulating emotions fall within the scope of the action of the system of valuation (d2), and can focus on any stages of the previous valuation system: (a1) world - situation selection and situation modification; (b1) perception - attentional deployment; (c1) assessment - cognitive change; (d1) action - response modulation.

Gross (2015) further subdivides the regulation of emotions into three functionally linked stages and each of which involves a valuation: (I) identification decision-making as to whether to regulate/alter or not an emotion/situation; (II) selection - choice of the regulation strategy to be used; and (III) implementation implementing a possible tactic of the chosen strategy. Therefore, according to the extended model, regulation of emotions is complex, and may present flaws in any of the three stages described and in any of the points of the valuation systems, a factor that can explain the variations in form and effectiveness of emotion regulation in different individuals.

Some studies have investigated the importance and role of ER in childhood and adolescence. For example, Cruvinel and Boruchovitch (2011) found that children with depressive symptoms experience anger and sadness more frequently, and use less diversified strategies to deal with sadness compared to a control group.

In a study conducted with students attending the 3rd grade of elementary school, Amaral (2014) found that boys usually inhibit behavior related to joy and sadness, seek fewer pleasurable situations as a strategy to regulate these emotions and have greater difficulty in controlling behavior in unpleasant situations. Girls, in turn, invest in pleasurable activities and seek the help of other people. However, after a program of development of emotional and social skills, children of both sexes demonstrated a more comprehensive understanding of the regulation strategies that could be used in varied situations, such as the decrease in aggressiveness among them, which shows the importance of intervention projects in this age group.

In the school context, emotions can significantly influence student learning and achievement, although this is not a linear relationship. Neves and Carvalho 
(2006) observed that affection permeates motivation for the study as well as the students' performance in mathematics. Similarly, Santos and Graminha (2006) point to a significant association between the occurrence of impulsive behaviors and difficulties in relation to attention in children with low school performance.

Realizing the importance that emotion regulation can present in the school context and observing the lack of an instrument with good psychometric properties to assess it, Ricarte (2016) developed an instrument for the evaluation of emotion regulation in children and adolescents in the Brazilian educational context, the Emotion Regulation Inventory for Learning Situations (IREmos Aprender). It is a self-report instrument, developed based on the theoretical perspective of Gross (1998), composed of 34 affirmations (items), whose responses are given by means of a 5-point-Likert-scale. The option for the theoretical model of 1998 occurred because it was the only one available when the instrument began to be developed.

This instrument was applied to 365 children and adolescents, with ages ranging from 9 to 15 years (M $=11.9 ; \mathrm{SD}=1.72)$. An exploratory factorial analysis (EFA), with extraction of the factors by main component analysis and oblique rotation, revealed a factorial structure with five factors, similar to the strategies of emotion regulation initially proposed by Gross (1998).

Factor $1(\alpha=0.615)$ had eight items related to the situation modification and attentional deployment (for example, before studying I turn off electronic devices to avoid distractions). Factor $2(\alpha=0.587)$ grouped seven items related to $\operatorname{cog}$ nitive change (for example, when the class is boring, I try to imagine the applicability of what is being studied in my daily life). The seven items that composed factor $3(\alpha=0.506)$ referred to the regulation of negative emotion, which refers to not being let down by sadness, discouragement or fear, being able to overcome frustrations of daily life through generation of appropriate feelings to deal with the tasks to be performed (for example, I feel bad when I don't understand the subject, so I try to focus more in class). This Factor was not identified as compatible with the ER strategies proposed by Gross (2008), suggesting the need for studies to investigate differences in the processing of positive and negative emotions (Ricarte, 2016). Factor 4 ( $\alpha=0.707)$ had four items related to the situation selection (for example, I try to sit in the front to avoid being distracted by other things in class). And, finally, Factor 5 $(\alpha=0.380)$ brought together four items related to response modulation (for example, I try not to show my friends that I am upset when I do poorly in a test). Despite the similarities to Gross's model of emotional regulation (1998, 2008, 2015), the author pointed out the need for revision of the instrument, especially with a view to improving its predominantly low accuracy indices and the representativeness of the content of the items, which often referred to non-emotional factors (for example, being hungry), which supposedly had an emotional implication that was not explicit (Ricarte, 2016).

The present study emerged from the need to obtain more in-depth information that can be taken as a basis for the revision of the Emotional Regulation Inventory for Learning Situations (IREmos Aprender), and the importance of obtaining a test with good psychometric properties to conduct studies on the emotional regulation of children in the school context. The objective was to investigate the psychometric properties of the mentioned instrument with the aid of the Item Response Theory (IRT). More specifically, the Rasch Model was used to investigate the following aspects: (a) adjustment of the items to the IRT model; (b) adequacy of the intensity of the construct represented in the items in relation to the ability presented by the participants (ceiling or floor effect); (c) latent trace analysis; and (d) probability of occurrence of response categories. Thus, it was expected to obtain more in-depth indicators on what to change in the second version of the instrument.

\section{Method}

\section{Participants}

In order to perform this analysis, we used the same database that served to study the factorial validity of the instrument, composed of a sample of 365 students from the 5th to the 9th grades, who answered the IREmos Aprender. They were regularly enrolled in a private school in the city of Recife, with a mean age of 11.9 years $(\mathrm{SD}=1.72), 57.5 \%$ female and $42.5 \%$ male.

\section{Instruments}

Data collection was performed using two instruments: a sociodemographic questionnaire, to characterize the sample, and the Emotion Regulation Inventory for Learning Situations (IREmos Aprender) (Ricarte, 2016). The socioeconomic questionnaire collected personal, demographic and cultural information.

IREmos Aprender is a self-report instrument, based on Gross's (1998) theory of emotion regulation, composed of 34 items, whose objective is to measure the ER strategies for learning used by elementary school students. All items relate strategies of emotion 
regulation in events/situations of the school day, and are evaluated by phrases that request the association of a feeling or emotional state with a behavior aimed at favoring learning. Responses were given using a 5-point Likert scale, where extremes 1 and 5 meant "nothing" or "everything" to do with me, respectively.

\section{Proceedings}

The Project was submitted to the Research Ethics Committee (REC) of Universidade Federal de Pernambuco (protocol CAAE 54639416.7.0000.5208), following all the norms standardized by the National Health Council, according to Resolution 466/12. After the approval by the REC, data collection was performed based on the non-probabilistic criterion, for accessibility or free adhesion (Sarriá, Guardiã, \& Freixa, 1999), in which participants are invited to participate in the research voluntarily. Parents were contacted and clarified about the objectives and procedures of the research, and subsequently signed an Informed Consent Form (ICF) authorizing the participation of the child or adolescent for whom they were responsible. In addition, the children and adolescents signed the Informed Consent Term (ICF), agreeing with their participation in the research.

The instruments were applied collectively, in a classroom situation. Alongside this, the moment of application of the instruments always implied in the presence of the teacher and one of the authors of this study, allowing that possible doubts of the participants were clarified.

\section{Data analysis}

The software Winsteps Version 3.69.1.6 (Linacre, 2009) was used to analyze the data, with the help of the Rasch Model of IRT. First, the items were adjusted to the IRT model by observing the infit and outfit indices. The infit indices reveal the adjustment on more sensitive categories of discrimination, that is, in the areas of the item characteristic curve (ICC) where a small change in subjects' skill level $(\Theta)$ results in a significant difference for the probability of success $\mathrm{P}(\Theta)$, while the outfit index shows the adjustment in categories of low discrimination, such as in the ICC extremities (Couto \& Primi, 2011).

Then, it was verified the adequacy of the intensity of the construct represented in items (b) in relation to the mean ability presented by the participants $(\Theta)$, by comparing the mean $(\mathrm{Mb})$ and the variability $(\mathrm{DPb})$ of the difficulty of the items with the mean $(\mathrm{M} \Theta)$ and the variability (DPӨ) of subjects' ability. This analysis aimed to examine whether the difficulty of the items in the instrument was compatible with the level of ability to regulate emotions presented by the participants of the research. Later, the analysis of the latent trait was performed by identifying the contents of the items that could be responsible for changing its difficulty indexes (b).

Finally, the probability of occurrence of the response categories (5-point Likert scale) was assessed by observing theta values $(\Theta)$ at the thresholds between response categories $(1,2,3,4$, and 5$)$. In this case, it is possible to determine if there is a parallelism between the response categories and the variation in the intensity of the construct and whether these categories were necessary and sufficient for participants to assign their answers (Nunes et al., 2008).

\section{Results}

The first objective of this work was to investigate the adjustment of the data to the IRT Rasch Model, observing the infit and outfit values provided by Winsteps. In factor 1, the infit indices ranged from 0.74 (item 27) to 1.42 (item 8), and outfit indices ranged from 0.73 (item 27) to 1.42 (item 8). In Factor 2, the infit indices ranged from 0.88 (item 4 ) to 1,22 (item 10), and the outfit indices, from 0.83 (item 4) to 1.29 (item 10). In Factor 3, infit indices ranged from 0.75 (item 2) to 1.35 (item 5), and those of outfit from 0.76 (item 2) to 1.46 (item 5). In Factor 4, infit indices ranged from 0.89 (item 21) to 1.14 (item 7), and outfit indices from 0.86 (item 21) to 1.13 (item 7). Finally, in Factor 5, the infit indices ranged from 0.80 (item 34) to 1.21 (item 24), and outfit indexes from 0.77 (item 34) to 1.20 (item 24).

In general, the infit and outfit indices show that the items fit the Rasch Model, with values between the thresholds of 0.7 and 1.3, or slightly surpassing them (items 5 and 8), without prejudice to the measure (Nunes et al., 2008). This means that the data can be considered suitable for IRT modeling and that subsequent analyzes could be performed.

To verify the adequacy of the difficulty of the items $(b)$ to the level of ability of the participants $(\Theta)$, we compared the mean and the variability of the difficulty of the items with the mean and the variability of the subjects. These data are presented in Table 1.

The mean of participants' ability (theta) was equal to (Factor 4) or slightly higher (not reaching 0.5 logit) than the mean of difficulty of the items (centered in 
zero, by software standard). The dispersion measures (standard deviations) were higher in the subjects than in the items.

Latent trait analysis was performed by observing the content of the items when placed in decreasing order of intensity in the construct (b). Table 2 shows the difficulty parameters of the items that compose Factor 1 (Change in the situation/ focus of attention).

In Factor 1, item 8 was the least intense $(b=-0.432)$ and Item 26, the most intense ( $\mathrm{b}=0.298)$. We observed that items were concentrated in a range close to the difficulty, with intensity range lower than 1 between them. Table 3 shows the parameters of the items that make up Factor 2 (Cognitive Change).

Table 1.

Descriptive statistics

\begin{tabular}{ccccc}
\hline & \multicolumn{2}{c}{ People } & \multicolumn{2}{c}{ Items } \\
\cline { 2 - 5 } & $\mathrm{M}$ & $\mathrm{SD}$ & $\mathrm{M}$ & $\mathrm{SD}$ \\
\hline Factor 1 & 0.42 & 0.86 & 0.0 & 0.26 \\
Factor 2 & 0.28 & 0.67 & 0.0 & 0.26 \\
Factor 3 & 0.39 & 0.58 & 0.0 & 0.24 \\
Factor 4 & 0.07 & 1.24 & 0.0 & 0.40 \\
Factor 5 & 0.35 & 0.79 & 0.0 & 0.30 \\
\hline
\end{tabular}

In Factor 2, Item 16 was the least intense (b = $-0.287)$ and Item 3 was the most intense $(b=0.598)$. It is observed that all items except Item 3 are very close in terms of difficulty, with difference of less than one logit between the extremes. Table 4 presents the parameters of the items that compose Factor 3 (Negative emotion regulation).

We observed that, in Factor 3, the intensity of the items ranged from -0.331 (Item 14) to 0.436 (Item 5). Table 5 shows the parameters of the items that compose Factor 4 (situation selection).

In Factor 4, Item 7 was the least intense (-0.397) and Item 21, the most intense (0.647). Table 6 shows the difficulty parameters of the items that compose Factor 5 (response modulation).

In Factor 5, the intensity of the items for the construct ranged from -0.457 (Item 24) to 0.287 (Item 34). Table 7 shows the probability of occurrence of response categories, according to theta thresholds. The values that appear in this table represent the point at which a response category becomes the most likely. For example, in Factor 1, from the -0.31 point the most likely category is no longer 1 and becomes 2 . However, the data reveals a problem, since category 3 becomes the most probable before category 2 , at the point of theta -0.54 . From theta 0.41 , category 4 becomes the most likely, but from theta 0.44 , category 5 becomes the most likely.

Table 2.

Parameters of Difficulty of Factor 1 Items

\begin{tabular}{|c|c|c|}
\hline $\begin{array}{l}\text { Number of } \\
\text { items }\end{array}$ & Mean (b) & Items \\
\hline 26 & 0.298 & Before studying I turn off electronics to avoid distractions \\
\hline 32 & 0.284 & $\begin{array}{l}\text { I choose to study in places where I don't have access to social media or games to } \\
\text { avoid distraction. }\end{array}$ \\
\hline 15 & 0.213 & $\begin{array}{l}\text { When I am hungry or tired at the end of the class, I try to focus more on the } \\
\text { teacher's explanations. }\end{array}$ \\
\hline 27 & 0.133 & $\begin{array}{l}\text { When I realize that games or social media distract me, I turn them off to focus on } \\
\text { studies. }\end{array}$ \\
\hline 17 & 0.012 & When I am discouraged to study something, I try to study anyway. \\
\hline 28 & -0.220 & $\begin{array}{l}\text { When there are noises at home disturbing me while I am studying, I try to pay more } \\
\text { attention to the studies and minimize the importance of these noises. }\end{array}$ \\
\hline 23 & -0.289 & $\begin{array}{l}\text { When there are external noises disturbing the progress of the lesson, I try to ignore } \\
\text { them and pay more attention to what is happening in class. }\end{array}$ \\
\hline 8 & -0.432 & $\begin{array}{l}\text { When I'm trying to study at home, but I feel uncomfortable with the noise of the } \\
\text { TV or stereo, I ask people to turn the volume down or turn it off. }\end{array}$ \\
\hline
\end{tabular}


Table 3.

Parameters of Difficulty of Factor 2 Items

\begin{tabular}{|c|c|c|}
\hline $\begin{array}{l}\text { Number of } \\
\text { items }\end{array}$ & Mean (b) & Items \\
\hline 3 & 0.598 & $\begin{array}{l}\text { When the class is boring, I try to imagine applications of what is being studied in my } \\
\text { daily life. }\end{array}$ \\
\hline 11 & 0.031 & $\begin{array}{l}\text { When I have to study something I don't like, I think my family members will be happy } \\
\text { because I am dedicated. }\end{array}$ \\
\hline 9 & -0.031 & $\begin{array}{l}\text { When I feel frustrated because a job is difficult to accomplish, I try to remember that I } \\
\text { have overcome other obstacles before. }\end{array}$ \\
\hline 4 & -0.079 & I try to find some practical meaning in the subjects I am studying to avoid boredom. \\
\hline 30 & -0.089 & When I'm anxious to take a test, I try to think of other things to relax and get good results. \\
\hline 10 & -0.144 & I choose the hours in which I like to study the most \\
\hline 16 & -0.287 & $\begin{array}{l}\text { When I interrupt my studies to do something nicer, I think how good it would be to } \\
\text { get good grades to go on vacation sooner. }\end{array}$ \\
\hline
\end{tabular}

Table 4.

Parameters of Difficulty of Factor 3 Items

\begin{tabular}{ccl}
\hline $\begin{array}{c}\text { Number of } \\
\text { items }\end{array}$ & Mean (b) & \multicolumn{1}{c}{ Items } \\
\hline 5 & 0.436 & $\begin{array}{l}\text { I choose whom I'm going to work with in a group so I don't have to worry about } \\
\text { the grade I'm going to take. } \\
\text { When I feel uncomfortable with my classmates' conversation, I ask for silence so I } \\
\text { can concentrate on the lesson. } \\
\text { When there are noises that bother me, I usually close the door of the room where I } \\
\text { am studying. } \\
\text { When I get nervous about not being able to solve an exercise, I try to calm myself } \\
\text { down before trying to resolve it again. } \\
\text { I have a bad feeling when I don't understand the subject, so I try to focus more in class. } \\
\text { When I feel uncomfortable because some schoolmate is not collaborating in a group } \\
\text { work, I ask him or her to collaborate more. }\end{array}$ \\
\hline
\end{tabular}

Table 5.

Parameters of Difficulty of Factor 4 Items

\begin{tabular}{ccl}
\hline $\begin{array}{c}\text { Number of } \\
\text { items }\end{array}$ & Mean $(\mathrm{b})$ & \multicolumn{1}{c}{ Items } \\
\hline 21 & 0.647 & $\begin{array}{l}\text { I try to seat at a distance from the schoolmates I like to chat with, to avoid } \\
\text { distracting me. }\end{array}$ \\
13 & -0.023 & $\begin{array}{l}\text { I try to sit in the front to avoid distracting myself with other things in class } \\
\text { The conversations of my schoolmates in the classroom irritate me, so I try not to } \\
\text { pay attention to these conversations, to be able to concentrate on the lesson. } \\
\text { I choose (or would like to choose) my seat in class, so as not to be bothered by } \\
\text { schoolmates who like chatting during class. }\end{array}$ \\
\hline
\end{tabular}


Table 6.

Parameters of Difficulty of Factor 5 Items

\begin{tabular}{ccl}
$\begin{array}{c}\text { Number of } \\
\text { Items }\end{array}$ & Mean (b) & \\
\hline 34 & 0.287 & $\begin{array}{l}\text { I often disguise my bad mood when I have to perform activities with schoolmates. } \\
\text { I try not to show my friends that I am upset when I have poor results in an } \\
\text { evaluation. } \\
6\end{array}$ \\
$\begin{array}{c}\text { When I have to perform an activity with a group of people with whom I don't get } \\
\text { along well, I try not to express my feelings so as not to compromise the group work. } \\
\text { When I am discouraged to go to school, I think of something nice I will find there. }\end{array}$ \\
24
\end{tabular}

Table 7.

Probability of occurrence of response categories in Factor 11

\begin{tabular}{cccccc}
\hline Categories & F1 & F2 & F3 & F4 & F5 \\
\hline 1 & zero & zero & zero & zero & zero \\
2 & -0.31 & 0.09 & 0.06 & -0.60 & 0.33 \\
3 & -0.54 & -0.47 & -0.37 & -0.73 & -0.70 \\
4 & 0.41 & 0.31 & 0.26 & 0.70 & 0.23 \\
5 & 0.44 & 0.07 & 0.04 & 0.63 & 014 \\
\hline
\end{tabular}

Thus, category 2 is not the most likely in any region of theta and category 4 is the most likely in a very narrow region of theta, therefore both are underutilized by subjects in Factor 1. However, a similar situation occurs in the other factors, suggesting that categories 2 and 4 could be collapsed, respectively, with categories 1 and 5 , using only three categories of response in the instrument as a whole.

\section{Discussion}

Based on the analysis of the descriptive statistics, it was observed that the difficulty indexes of the items extend through a very narrow skill range, less than one logit and close to the difficulty mean, in all factors. Also, the mean for subjects' skills was slightly higher than the difficulty mean of items in all factors, except for Factor 4, where subjects' mean ( $\mathrm{M}=0.07)$ was very close to the mean of the items (centered in zero by default). These data suggest that the instrument may fail to evaluate subjects with extreme skill levels (high or low) and that it is necessary to construct more items for the evaluation of these extremes or at least improve the variability of the difficulty of the items.
Pasquali (2007), for example, says that a typical distribution of the level of difficulty of the items is in 3 logits (deviations) both above and below the average. Therefore, the analysis of the latent trait of all the factors was performed, in order to identify the aspects that make an item easier or difficult, and thus to point out ways for the elaboration of new items in a future revision of the instrument.

Corroborating the descriptive statistics, latent trait analysis showed that the items have very close indices of difficulty, concentrating on the same intensity range of the construct (around the mean). Factor 1 was called Situation Modification/Attentional Deployment because it brought together items originally constructed to represent these two strategies for regulating emotions (Gross, 2008). However, a content analysis reveals that the items with lower level of difficulty refer to the control of external stimuli that interfere in the studies (items $8,23,28$ ), and the level of difficulty tends to increase as the internal control of distracting pleasurable motivations becomes necessary (items 17, 27 and 15). Finally, the greatest difficulty seems to be related to the anticipation of the need for emotion regulation, when the subject foresees a possible distraction from 
the task and modifies the environment so that it does not occur (items 26 and 32).

Factor 2 was called cognitive change, because it is compatible with this strategy of emotion regulation (Gross, 2008). In this factor, two sets of items evaluate very close levels of difficulty of the construct ( 9 and 11, 4, 10 and 30). We observed that the group of items that compose this factor proposes the recovery of ideas related to positive consequences or learning experiences that are motivating in relation to the discipline required to study (for example, to think that it would be good to go on holiday earlier, to think about other things to relax, to think that he or she has overcome obstacles before or that the family members will be happy with a good performance), except for item 3 , which keeps the focus on the content in study, trying to extend the student's understanding from possible examples (imagine applications of what is being studied for daily life). Thus, for the development of more difficult items, it seems fruitful to invest in strategies that focus on learning, seeking to assign practical meaning to what is being learned at the moment. This type of skill may be important for what has now been called active learning, in which the student engages in more practical activities and must have greater responsibility and autonomy in relation to learning (Mesquita, Meneses, \& Ramos, 2016). Similar factors were obtained in other studies (e.g. Gross \& John, 2003) and results seem to indicate that the use of this type of strategy is related to a healthier affective, cognitive and social functioning (John \& Gross, 2004).

The items of Factor 3, regulation of negative emotions, present different strategies (situation selection, situation modification, attentional deployment) to deal with a more general negative emotion (worry, annoyance, nervousness, annoyance). Although not consistent with Gross's (2008) proposal, this factor is consistent with findings from other studies. The Emotion Regulation Profile (ERP), for example, has a down regulation factor, whose functional strategies are very similar to those employed in this study (situation modification, attentional deployment, positive reassessment of the situation and expression of emotions) (Gondim et al., 2015).

From the analysis of the items of Factor 3 it is possible to observe that one of items 2 or 22 can be eliminated in a future revision of the instrument, since they are evaluating the same intensity of the construct. Like Factor 1, the difficulty of the items seems to increase as the emotional regulation goes from corrective (after the nuisance is noticed) to preventive, by anticipation of the situation that would generate the negative emotion.

Factor 4 gathered items related to situation selection, one of the strategies of emotion regulation proposed by Gross (2008). By analyzing the content of the items of this factor, it can be observed that items 7 , 13 and 19 present generic situations in which people try to find a more appropriate situation to pay attention in class (sitting in the front or away from people chatting, not paying attention to parallel chatting). On the other hand, item 21, with the highest difficulty index, involves a relational question (sitting far from schoolmates with whom one likes to talk to), with a possibility of social consequence, since sitting away from friends can lead the young person to be disapproved and/or to distance themselves from their group of preferential coexistence. Thus, in a future revision of the instrument, the development of more difficult items can be achieved by describing more personal situations in which regulation involves a more proactive action that goes in the opposite direction of what would be more pleasurable and socially desirable for the student.

Finally, Factor 5, response modulation, is also composed of items that describe a strategy compatible with the theoretical proposal of Gross (2008). Item 24 was the easiest because it deals with a generic situation, which involves overcoming inertia to go to school. Items 6 and 31 are about containing the expression of some negative feeling toward peers, and 34 seems to be the most complex because it involves not only the containment of the expression, but the disguise, that is, the production of an expression that is not compatible with the internal physiological state, but that would be more appropriate from the social point of view. This factor was also obtained in previous studies, which show that emotional suppression is a strategy for regulating emotions that produces negative effects on healthy mental and interpersonal functioning (Gross \& John, 2003; John \& Gross, 2004).

Based on these item content analyzes, we can identify the elements that produce changes in the level of skill required for the respondent to agree with the item. In general, it was observed that emotion regulation becomes more difficult as the necessary actions go from the modification of elements in the environment to the modification of internal dispositions and, finally, to anticipation and taking the necessary measures to avoid the problem. Even at the internal level, solutions such as diverting the focus of thought from the task 
being performed are easier because, in a way, they lead the subject to think of situations external to the one he is experiencing and in extrinsic motivations, while the reinterpretation of the situation with a focus on learning is more difficult.

In addition, regulating emotionally and/or socially attractive behaviors (e.g., avoiding sitting close to schoolmates with whom one likes to talk) is more difficult than more generic steps, such as sitting in the front, for example. Understanding how emotion regulation becomes more difficult is important because it can guide ways to intervene (rather than guiding the child to stay away from a friend, which would involve more personal control, guide her to sit in the front, which would be more impersonal) and for the elaboration of items to assess higher levels of ability in emotion regulation.

Although it was not part of the objectives proposed in this study, another aspect deserves to be registered. In content analysis, many items were identified that do not refer to emotions as such, but rather to other physical states, such as hunger. Although it is recognized that these other states may have emotional implications, the strategies may not refer to an emotion in itself, but to self-regulating behaviors (Simão \& Frison, 2013). Therefore, in future studies of revision of this instrument, we suggested the explicitness of the emotion under the focus of regulation.

Finally, the analysis of the probability of occurrence of response categories showed that categories 2 and 4 of the Likert scale were less likely in relation to the closest categories, 1 and 5. Thus, the subjects attributed their answers predominantly to categories 1, 3 and 5 , so the instrument response scale can be reduced to three points, maintaining its accuracy, which can also be implemented in a new version of the instrument.

\section{Final Considerations}

The objective of this study was to clarify the psychometric properties of an Emotional Regulation Inventory built in a previous study, in order to obtain information that contributes to its revision. We understand that the literature in the field of emotion regulation and its relation with learning is still scarce, therefore the validation of a psychological evaluation instrument is relevant to foment studies on the subject and to enable future interventions in the area.

With the aid of the Item Response Theory (IRT), it was possible to obtain some important information for the revision of the instrument: (a) there is a need to create new items, capable of evaluating a greater range of ability to regulate emotions, especially for higher levels of ability; (b) it is pertinent to exclude items that evaluate the same intensity of the construct, since they do not contribute for the consistency of the instrument, and may make it too long to be applied to young students; and (c) a 3-point scale (instead of 5 points) seems to be more appropriate for participants to assign their answers. In addition, the use of IRT enabled a more precise content analysis regarding the elements that could interfere in the difficulty of the instrument items, which may be the basis for the revision and elaboration of new items for a new version of the instrument.

This study presents limitations, such as a sample defined by convenience restricted to children and adolescents of private schools in a large city in Northeastern Brazil, whose results have to be confirmed with children from other cultural contexts. However, it presents important data for the continuity of the development of an instrument to assess the skills of emotion regulation for learning and to understand the phenomenon studied.

\section{References}

Amaral, S. M. (2014). Promovendo a Regulação Emocional em Crianças do $1^{\circ}$ Ciclo do Ensino Básico: Um programa de competências emocionais e sociais. Dissertação de mestrado. Departamento de ciências da educação, Universidade dos Açores, Ponta Delgada. Recuperado de https://repositorio.uac.pt/ bitstream/10400.3/3358/2/DissertMestradoSandraCristinaMachadoAmaral2015.pdf

Barrett, L. F., Ochsner, K. N., \& Gross, J. J. (2007). On the automaticity of emotion. Social psychology and the unconscious: The automaticity of higher mental processes, 173, 217.

Couto, G., \& Primi, R. (2011). Teoria de resposta ao item (TRI): Conceitos elementares dos modelos para itens dicotômicos. Boletim de Psicologia, 61(134), 001-015. Recuperado de http:// pepsic.bvsalud.org/scielo.php?script $=$ sci_ arttext\&pid=S0006-59432011000100002\&lng=pt \&tlng $=\mathrm{pt}$

Cruvinel, M., \& Boruchovitch, E. (2011). Regulação emocional em crianças com e sem sintomas de depressão. Estudos de Psicologia, 16(3), 219-226. DOI: 10.1590/S1413-294X2011000300003 
Freud, S. (1976). Um estudo autobiográfico, Inibições, Sintomas e Ansiedade a Questão da Análise Leiga e Outros Trabalhos. In S. Freud, Edição Standard brasileira das obras psicológicas completas de Sigmund Freud (J. Salomão, trad., Original publicado em 1926; Vol. XX). Rio de Janeiro: Imago.

Gondim, S. M. G.; Pereira, C. R.; Hirschle, A. L. T.; Palma, E. M. S.; Alberton, G. D.; Paranhos, J.; Santana, V., \& Ribeiro, W. R. B. (2015). Evidências de Validação de uma Medida de Características Pessoais de Regulação das Emoções. Psicologia: Reflexão e Crítica, 28(4), 659-667. https://dx.doi. org/10.1590/1678-7153.201528403

Gross, J. J. (1998). The emerging field of emotion regulation: An integrative review. Review of General Psychology, 2, 271-299. DOI: 10.1037/1089-2680.2.3.271

Gross, J. J. (2008). Emotion regulation. In M. Lewis, J. M. Haviland-Jones, \& L. F. Barrett (Eds.), Handbook of emotions. New York: Guilford Press.

Gross, J. J. (2015). Emotion Regulation: Current Status and Future Prospects, Psychological Inquiry, 26, 1-26. DOI: $10.1080 / 1047840 X .2014 .940781$

Gross, J., \& John, O. (2003). Individual differences in two emotion regulation processes: Implications for affect, relationships, and well-being, Journal of Personality and Social Psychology, 85(2), 348-362. DOI: http://dx.doi.org/10.1037/0022-3514.85.2.348

Gross, J., \& Thompson, R. (2007). Emotion regulation: Conceptual foundations. In J. Gross (Ed.), Handbook of emotion regulation. New York: Guilford Press.

John, O., \& Gross, J. (2004). Healthy and Unhealthy Emotion Regulation: Personality Processes, Individual Differences, and Life Span Development. Journal of Personality, 72(6), 1301-1334. DOI: 10.1111/j.1467-6494.2004.00298.x

Linacre, J. M. (2009). Winsteps Rasch Measurement - Version 3.69.16. Recuperado de http://www. winsteps.com/winsteps.htm

Mayer, J. D., \& Salovey, P. (1990). Emotional intelligence. Imagination, cognition and personality, 9(3), 185-211. DOI: 10.2190/DUGG-P24E-52WK-6CDG

Mayer, J. D., \& Salovey, P. (1997). What is emotional intelligence? In P. Salovey \& D. J. Sluyter (Eds.), Emotional development and emotional intelligence. New York: Basic Books, 3-31.
Mesquita, S. K. C.; Meneses, R. M. V., \& Ramos, D. K. R. (2016). Metodologias ativas de ensino/aprendizagem: dificuldades de docentes de um curso de enfermagem, Trab.Educ.Saúde, 14(2),473-486.DOI: http://dx.doi.org/10.1590/1981-7746-sip00114

Neves, M. C., \& Carvalho, C. (2006). A importância da afectividade na aprendizagem da matemática em contexto escolar: Um estudo de caso com alunos do 8. ${ }^{\circ}$ ano. Análise Psicológica, 24(2), 201-215. Recuperado de http://hdl.handle.net/10400.12/6005

Nunes, C., Primi, R., Nunes, M., Muniz, M., Cunha, T. \& Couto, G. (2008). Teoria de Resposta ao Item para otimização de escalas tipo likert- um exemplo de aplicação Revista Iberoamericana de Diagnóstico y Evaluación, RIDEP, 1(25), 51-79. Recuperado de http:// www.redalyc.org/articulo.oa?id $=459645445004$

Pasquali, L. (2007). Teoria de Resposta ao Item (TRI). Laboratório de Pesquisa em Avaliação e Medida (LabPAM/UnB), Brasilia, DF.

Ricarte, M. D. (2016). Construção de um Instrumento para Avaliação da Regulação Emocional em Crianças e Adolescentes. Dissertação de Mestrado não-publicada. Programa de Pós-Graduação em Psicologia Cognitiva, Universidade Federal de Pernambuco, Recife.

Saarni, C. (1999). A Skill-Based Model of Emotional Competence: A Developmental Perspective. Trabalho apresentado na Reunião Bienal da Sociedade de Pesquisa em Desenvolvimento da Criança, Albuquerque, NM, 15-18 Abr. 1999 (18p.). Recuperado de https://files.eric.ed.gov/fulltext/ ED430678.pdf

Santos, P. L., \& Graminha, S. S. V. (2006). Problemas emocionais e comportamentais associados ao baixo rendimento acadêmico. Estudos de Psicologia (Natal), 11(1), 101-109. DOI: 10.1590/ S1413-294X2006000100012

Sarriá, A., Guardiã, J., \& Freixa, M. (1999). Introducción a la estadística en Psicología. Barcelona: Ediciones de la Universitat de Barcelona.

Simão, A. M. V., \& Frison. L. M. B. (2013). Autorregulação da aprendizagem: abordagens teóricas e desafios para as práticas em contextos educativos, Cadernos de Educação, 45, 2-20.

Recebido em: 07/03/2018

Reformulado em: 13/08/2018

Aprovado em: 29/08/2018 
Sobre os autores:

Mirela Dantas Ricarte is a psychologist. She holds a Master's and PhD degree in Cognitive Psychology from Universidade Federal de Pernambuco (UFPE). Professor of Psychology at UNIFAVIP/Wyden University Center and researcher at the Center for Studies in Psychological Assessment (NEAP/ UFPE).

ORCD: 0000-0001-9225-0856

Email: mirelaricarte@yahoo.com.br

Fernanda Mírian França Silva is an undergraduate student in Psychology at Universidade Federal de Pernambuco (UFPE). She holds a Scientific Initiation Scholarship from CNPq and is a member of the Nucleus of Studies in Psychological Evaluation (NEAP/UFPE).

ORCD: 0000-0003-2117-8441

Email: fernanda.mirianfs@hotmail.com

José Maurício Haas Bueno is a psychologist. Holds a PhD in Psychology from Universidade de São Francisco (USF). Professor of the Graduate Program in Cognitive Psychology at Universidade Federal de Pernambuco (UFPE) and coordinator of the Center for Studies in Psychological Assessment (NEAP/ UFPE).

ORCD: 0000-0002-9179-7216

Email: mauricio.ufpe@gmail.com

Contato com os autores:

Universidade Federal de Pernambuco, Centro de Filosofia e Ciências Humanas. Cidade Universitária

Recife-PE, Brazil

CEP: 50670-901

Telefone: (81) 2126-8000 